\title{
Echocardiographic diagnosis of a massive left ventricular pseudoaneurysm: a case report
}

\author{
Nadezhda Sokolskaya, Natalya Kopylova, Inessa Slivneva, Yan Kolesnikov, Michail Alshibaya, \\ Mariya Zakharkina
}

Institute of Coronary and Vascular Surgery of the A.N. Bakoulev Center for Cardiovascular Surgery,

Russian Academy of Medical Sciences, Moscow, Russian Federation

Kardiochirurgia i Torakochirurgia Polska 2015; 12 (2): 181-183

\begin{abstract}
Left ventricular aneurysm is one of the most troublesome complications of myocardial infarction. This complication results from LV wall rupture and presents as a cavity contained by pericardium and fragments of the ruptured wall. The risk of pseudoaneurysm rupture is very high and this makes the prognosis for the disease extremely unfavorable. A surgical correction, involving a patch repair of the LV wall, seems to be the only treatment modality. Echocardiography makes it possible to diagnose pseudoaneurysm of the left ventricle in most cases, while intraoperative transesophageal echocardiography is required for the in-process monitoring of intracardiac hemodynamics and assessment of intervention efficiency.

Key words: transesophageal echocardiography, left ventricular pseudoaneurysm.
\end{abstract}

\section{Introduction}

Pseudoaneurysm of the left ventricle (LV) usually develops following ventricular rupture due to transmural myocardial infarction [1]. Female sex, age, previous stroke, ST elevation, positive cardiac biomarkers, and heart rate at presentation were independently related to heart rupture [2].

Massive pericardial tamponade is the most common cause of fatal outcome of patients with free wall rupture, but in some cases, the thrombus becomes organized within the limits of the surrounding tissues and pericardium, which results in pseudoaneurysm formation [1-4]. The risk of pseudoaneurysm rupture is very high, and this makes the prognosis for the disease extremely unfavorable. A surgical correction, involving a patch repair of the LV wall, seems to be the only treatment modality [1-4].

Echocardiography is a tool to diagnose left ventricular pseudoaneurysm.

\section{Streszczenie}

Tętniaki lewej komory stanowią jedno z najbardziej problematycznych powikłań zawału mięśnia sercowego. Wynika ono z pęknięcia ściany lewej komory, a objawia się obecnością jamy ograniczonej osierdziem i fragmentami pękniętej ściany. Ryzyko pęknięcia tętniaka rzekomego jest bardzo wysokie, toteż rokowanie w takich przypadkach jest skrajnie niekorzystne. Korekcja chirurgiczna wady związana z naszyciem łaty na ścianę lewej komory wydaje się jedyną możliwością leczenia. W większości przypadków echokardiografia umożliwia zdiagnozowanie tętniaka rzekomego lewej komory; z kolei śródoperacyjna echokardiografia przezprzełykowa konieczna jest do monitorowania hemodynamiki wewnątrzsercowej i oceny skuteczności interwencji.

Słowa kluczowe: echokardiografia przezprzełykowa, tętniak rzekomy lewej komory.

We report a patient who developed acute myocardial infarction followed by massive posterior LV pseudoaneurysm, diagnostics and its successful surgical treatment: the Dor procedure and coronary artery bypass grafting.

\section{Case study}

Patient F., 51 years old, who presented with a onemonth history of episodes of chest pain, was admitted to the emergency department. He had not been referring to doctors and due to this was not receiving therapy. He had complaints of acute chest pain with radiation to the left shoulder and dyspnea. On auscultation normal heart sounds and a midsystolic murmur grade II/VI were heard. Blood pressure was 160/110 mmHg. Complete physical examination revealed no further abnormalities. ECG showed ST-segment elevation in leads II, III, and AVF.

Coronary angiography revealed a subtotal stenosis of the anterior interventricular branch, and right coronary ar-

Address for correspondence: Prof. Nadezhda Sokolskaya, Institute of Coronary and Vascular Surgery of the A.N. Bakoulev Center for Cardiovascular Surgery, Russian Academy of Medical Sciences, 8 bldg 7 Leninsky Prospekt, 117931 Moscow, Russian Federation, phone: + 89851073015, e-mail: mary39409@rambler.ru 
tery occlusion. The patient underwent transthoracic echocardiography, which revealed moderately reduced ejection fraction (LV EF 37\%), dilation of the left ventricle (end diastolic volume (EDV) was $341 \mathrm{ml}$ ), and dilation of the atria. Moreover, there were posterior LV dyskinesia and a defect of LV posterior and posteroseptal walls with aneurysm. LV aneurysm volume was $400 \mathrm{ml}$. Also moderate mitral regurgitation and mild to moderate tricuspid regurgitation were found.

Based on clinical information and instrumental findings, the following diagnosis was made: Coronary artery disease. Acute myocardial infarction followed by posterior LV aneurysm. Paroxysmal atrial fibrillation. Chronic heart failure, functional class: 2 .

On the basis of these findings, MI was treated conservatively, and the patient was prepared for surgery: coronary artery bypass grafting and the Dor procedure. After stabilization of the severity of the condition and to obtain patient consent for surgery, the patient was admitted for surgical treatment to the Institute of Coronary and Vascular Surgery of the A.N. Bakoulev Center for Cardiovascular Surgery.

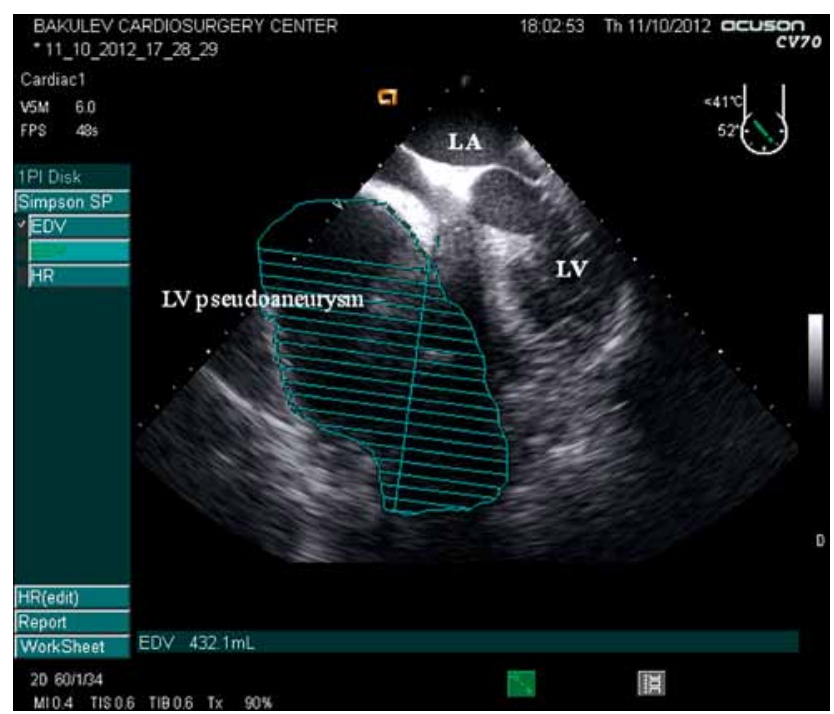

Fig. 1. Transesophageal echocardiography. LV pseudoaneurysm outlined $($ volume $=432 \mathrm{ml}$ )

$\mathrm{LV}$ - left ventricle, LA - left atrium

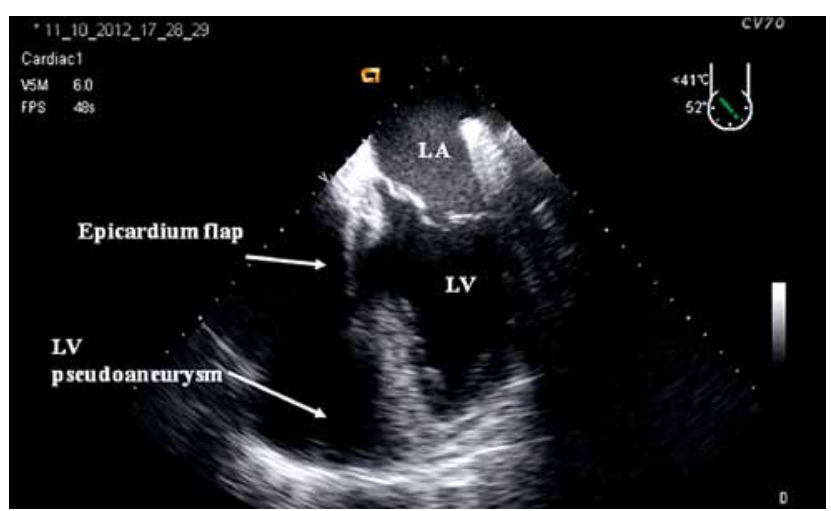

Fig. 2. Transesophageal echocardiography. LV pseudoaneurysm. Epicardium flap in the area of LV pseudoaneurysm neck (arrow) $L V$ - left ventricle, LA - left atrium
Blood pressure was 125/75 mmHg and pulse 65 beats/ min. ECG showed "persistent" Q-waves in leads II, III, and AVF. Before the operation, complex examination of the patient by the standard protocol was performed, the results of which showed that the patient did not have contraindications to surgery.

\section{Surgery}

The plan of the surgery included: mammary coronary bypass of the anterior interventricular branch, and the Dor procedure through hypothermic cardiopulmonary bypass. Prior to the principal stage of the operation, intraoperative transesophageal echocardiography was required to more precisely identify the aneurysm volume and assess the valvular abnormality.

Intraoperative TEE showed dilation of the LV (EDV $=270$ $\mathrm{ml}$ ) and moderately reduced EF (36\%). There was a defect of posterior and posteroseptal LV walls with a 430-ml pseudoaneurysm (Fig. 1). Color Doppler revealed a partially thrombosed LV aneurysm in the pseudoaneurysm cavity. The aneurysm neck presented with an echo-positive epicardium flap that closed the neck during systole like a valve (Fig. 2). The diameter of the aneurysm neck was $33 \mathrm{~mm}$ (Fig. 3). The longitudinal and transversal axes of the LV pseudoaneurysm cavity measured $89 \mathrm{~mm}$ and $55 \mathrm{~mm}$, respectively.

Mitral valve: the cusps appeared thin and mobile; we found moderate mitral regurgitation (Fig. 4). There was no sign of damage of the subvalvular apparatus of the mitral valve. The annulus of the mitral valve did not exceed 40 $\mathrm{mm}$. Tricuspid valve: the cusps appeared thin and mobile; tricuspid annulus $37 \mathrm{~mm}$; regurgitation of mild to moderate degree. There was echocardiographic evidence of pulmonary hypertension: the gradient between the right ventricle and right atrium was $30 \mathrm{~mm} \mathrm{Hg}$, and pressure of the right

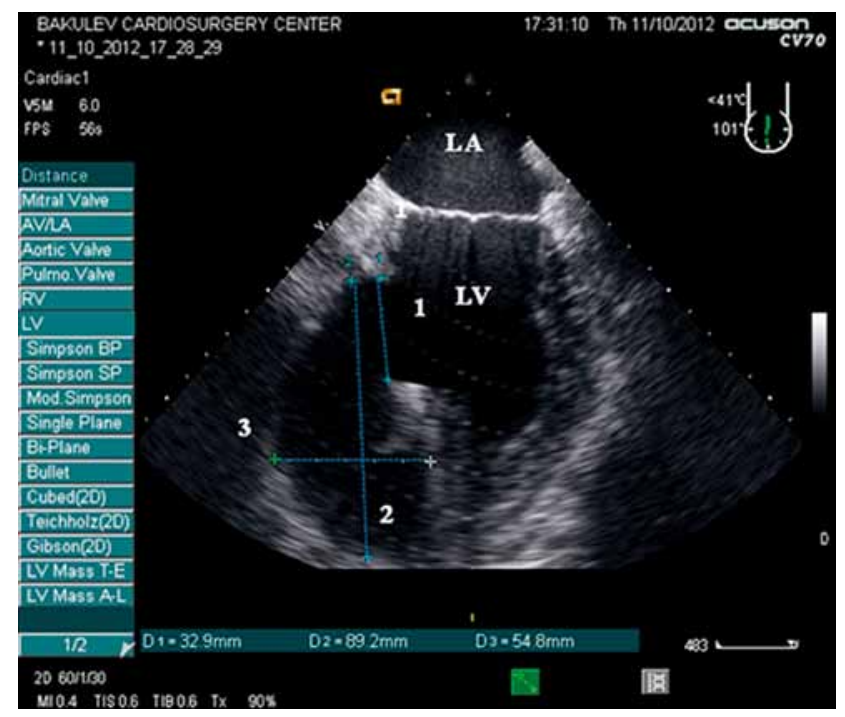

Fig. 3. Transesophageal echocardiography. Two-chamber view. LV pseudoaneurysm. Dimensions of cavity and diameter of connection with LV. 1 - neck diameter; 2 - longitudinal axis of LV aneurysm cavity; 3 - transverse axis of LV aneurysm cavity LV - left ventricle, LA - left atrium 


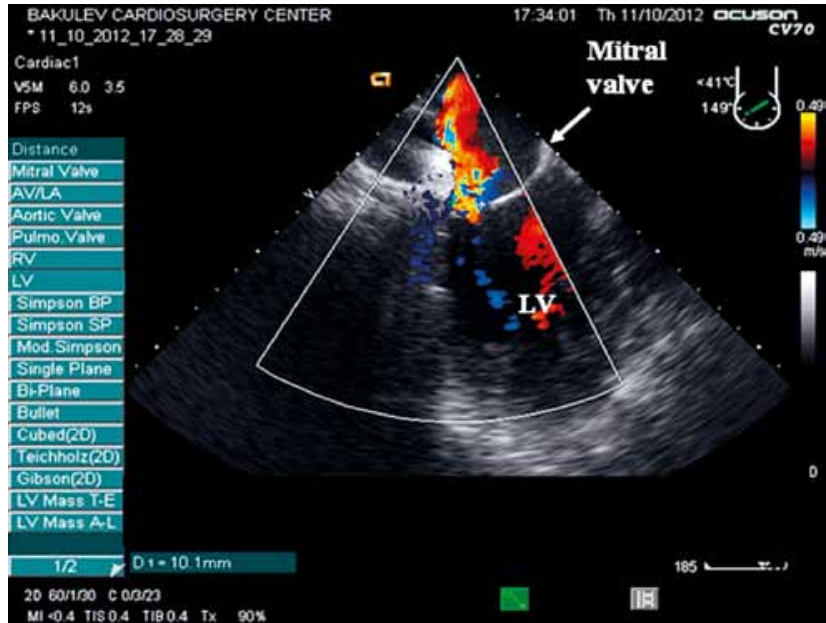

Fig. 4. Transesophageal echocardiography. Color Doppler mapping. Mitral incompetence mild to moderate LV - left ventricle

ventricle was estimated to be $30 \mathrm{~mm} \mathrm{Hg}+$ central venous pressure $10 \mathrm{~mm} \mathrm{Hg}=40 \mathrm{~mm} \mathrm{Hg}$. Assessment of right ventricular function included tricuspid annular plane systolic excursion (TAPSE) and tissue Doppler imaging of the tricuspid annulus (S). These parameters were $16 \mathrm{~mm}$ and $11 \mathrm{~cm} / \mathrm{s}$, respectively.

The surgical technique included LV pseudoaneurysm repair using an autologous pericardial patch. The pericardial patch was toughened with glutaraldehyde after resection, and shaped to close the ruptured area. We used a circular patch to reconstruct the left ventricle ("endoventricular circular plasty") in order to maintain physiologic cavity (the Dor procedure) [4].

After the principal stage of the operation, a checkup transesophageal examination was performed (Fig. 5). A patch in the LV wall defect site was clearly visible; LV EDV 200 ml, LV EF $36 \%$; mitral regurgitation was mild to moderate, tricuspid regurgitation was trace to mild.

The postoperative period was uneventful and, on the $2^{\text {nd }}$ day, the patient was transferred from the intensive care unit to an ordinary ward. On the $14^{\text {th }}$ day after the operation, the patient was discharged from the hospital.

Transesophageal echocardiography was performed 12 months after the operation. Follow-up data: LV EDV = $168 \mathrm{ml}$, LV EF $=41 \%$, mitral regurgitation was trace to mild. There were no problems with the patch. The patient's angina and chronic heart failure improved up to $1^{\text {st }}$ functional class. He has continued to take anti-arrhythmic medication with no atrial fibrillation paroxysm during the last year.

Two years after surgery, the patient has received conservative medical therapy and does not have episodes of chest pain. His physical examination is normal.

\section{Discussion}

Intraoperative transesophageal echocardiography plays an important role in clarifying cardiac anatomy and esti-

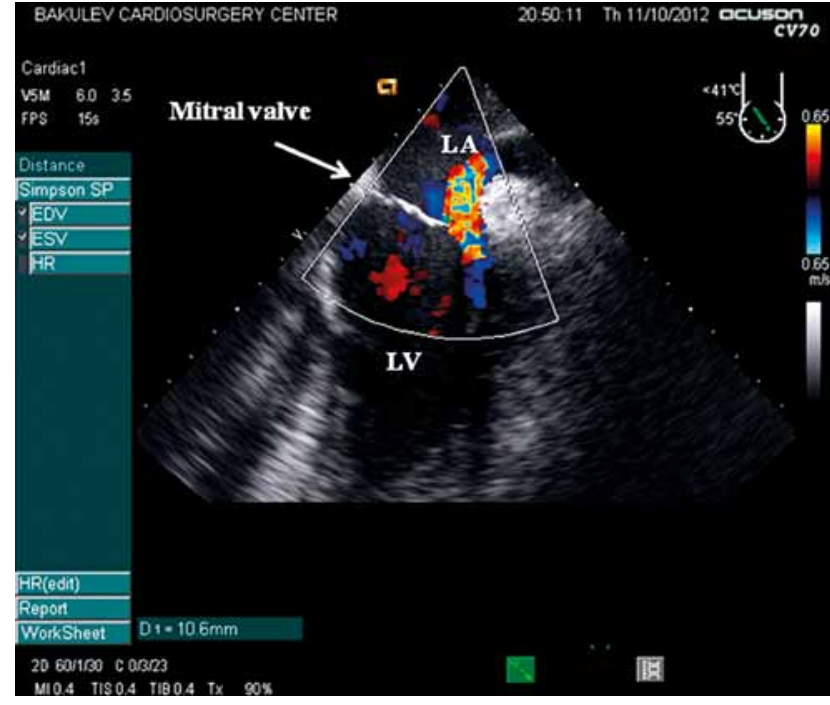

Fig. 5. Transesophageal echocardiography. Color Doppler mapping. Mitral incompetence II after principal stage of operation LV - left ventricle, LA - left atrium

mating left ventricular volumes, ejection fraction, and mitral regurgitation in patients with ischemic heart failure undergoing this surgery. Also echocardiography allows evaluation of the surgical results $[5,6]$.

The choice of the technique to close the neck of the pseudoaneurysm is based on the extent of the defect and the status of the myocardium. Pericardium is an excellent material for surgical repair of certain acquired defects [1].

There is a high risk of death when conservative treatment of pseudoaneurysms is used. Pseudoaneurysms can be repaired surgically, with acceptable mortality, until a more appropriate method becomes available [1].

\section{Disclosure}

Authors report no conflict of interest.

\section{References}

1. Fedakar A, Bugra O, Onk A, Mataraci I, Eren E, Zeybek R. Repair of left ventricular pseudoaneurysms. Asian Cardiovasc Thorac Ann 2010; 18: 39-43.

2. López-Sendón J, Gurfinkel EP, Lopez de Sa E, Agnelli G, Gore JM, Steg PG, Eagle KA, Ruiz Cantador J, Fitzgerald G, Granger CB for the Global Registry of Acute Coronary Events (GRACE) Investigators. Factors related to heart rupture in acute coronary syndromes in the Global Registry of Acute Coronary Events. Eur Heart J 2010; 31: 1449-1456.

3. Alshibaya MM, Buslenko NS, Dorofeev AV, et al. Effect of myocardial revascularization and geometrical LV reconstruction on mitral insufficiency in patients with ischemic cardiopathies and post-infarction cardiac aneurysms. Bul. A.N. Bakoulev RCCVS, RAMS 2008; 9: 171

4. Dor V, Saab M, Coste P, Kornaszewska M, Montiglio F. Left ventricular aneurysm: a new surgical approach. Thorac Cardiovasc Surg 1989; 37: 11-19.

5. Eren E, Bozbuga N, Toker ME, Keles C, Rabus MB, Yildirim O, Guler M, Balkanay $M$, Isik $O$, Yakut $C$. Surgical treatment of post-infarction left ventricular pseudoaneurysm: a two-decade experience. Tex Heart Inst J 2007; 34: 47-51.

6. Shiota T, McCarthy PM. Volume reduction surgery for end-stage ischemic heart disease. Echocardiography 2002; 19 (7 Pt 1): 605-612. 